\title{
The estrogen receptor $\alpha$-selective agonist propyl pyrazole triol improves glucose tolerance in ob/ob mice; potential molecular mechanisms
}

\author{
L Lundholm ${ }^{1}$ G Bryzgalova*, H Gao ${ }^{1}$, N Portwood, S Fält ${ }^{1}$, K D Berndt ${ }^{1}$, A Dicker ${ }^{2}$, D Galuska ${ }^{3}$, \\ J R Zierath ${ }^{3}$, J-Å Gustafsson ${ }^{1}$, S Efendic, K Dahlman-Wright ${ }^{1}$ and A Khan
}

Department of Molecular Medicine and Surgery, Karolinska Institute, Karolinska University Hospital, SE-171 76 Stockholm, Sweden

${ }^{1}$ Department of Biosciences and Nutrition, Karolinska Institute, SE-14157 Huddinge, Sweden

${ }^{2}$ Department of Medicine, Karolinska Institute, Karolinska University Hospital, SE-14186 Huddinge, Sweden

${ }^{3}$ Department of Molecular Medicine and Surgery, Karolinska Institute, SE-17176 Stockholm, Sweden

(Correspondence should be addressed to A Khan; Email: akhtar.khan@ki.se)

*(L Lundholm and G Bryzgalova contributed equally to this study)

\begin{abstract}
The aim of this study was to validate the role of estrogen receptor $\alpha(E R \alpha)$ signaling in the regulation of glucose metabolism, and to compare the molecular events upon treatment with the ER $\alpha$-selective agonist propyl pyrazole triol (PPT) or $17 \beta$-estradiol $\left(\mathrm{E}_{2}\right)$ in ob/ob mice. Female ob/ob mice were treated with PPT, $\mathrm{E}_{2}$ or vehicle for 7 or 30 days. Intraperitoneal glucose and insulin tolerance tests were performed, and insulin secretion was determined from isolated islets. Glucose uptake was assayed in isolated skeletal muscle and adipocytes. Gene expression profiling in the liver was performed using Affymetrix microarrays, and the expression of selected genes was studied by real-time PCR analysis. PPT and $\mathrm{E}_{2}$ treatment improved glucose tolerance and insulin
\end{abstract}

sensitivity. Fasting blood glucose levels decreased after 30 days of PPT and $\mathrm{E}_{2}$ treatment. However, PPT and $\mathrm{E}_{2}$ had no effect on insulin secretion from isolated islets. Basal and insulin-stimulated glucose uptake in skeletal muscle and adipose tissue were similar in PPT and vehicle-treated ob/ob mice. Hepatic lipid content was decreased after $\mathrm{E}_{2}$ treatment. In the liver, treatment with $\mathrm{E}_{2}$ and $\mathrm{PPT}$ increased and decreased the respective expression levels of the transcription factor signal transducer and activator of transcription 3 , and of glucose-6-phosphatase. In summary, our data demonstrate that PPT exerts anti-diabetic effects, and these effects are mediated via $E R \alpha$.

Journal of Endocrinology (2008) 199, 275-286

\section{Introduction}

The metabolic syndrome, defined by central obesity, hyperglycemia, decreased high-density lipoprotein, cholesterol, elevated triglycerides (TGs) and blood pressure, has become a major public health challenge worldwide (Zimmet et al. 2005). Changes in environment and lifestyle have escalated the rates of type 2 diabetes and obesity (Zimmet et al. 2005). Estrogen deficiency in postmenopausal women contributes to the development of visceral obesity, insulin resistance and the risk of developing type 2 diabetes (Louet et al. 2004), while treatment with $17 \beta$-estradiol $\left(\mathrm{E}_{2}\right)$ or conjugated equine estrogens improves insulin sensitivity and lowers blood glucose levels (Espeland et al. 1998, Crespo et al. 2002, Saglam et al. 2002). Results from the Women's Health Initiative study showed a reduced incidence of diabetes in postmenopausal women on hormone replacement therapy or after estrogen treatment alone (Margolis et al. 2004, Bonds et al. 2006). Moreover, hormone replacement therapy in postmenopausal women with coronary artery disease resulted in a $35 \%$ reduction in the incidence of type 2 diabetes at the 4-year follow-up (Kanaya et al. 2003).

Estrogen signals via binding to either of two estrogen receptors (ERs), $E R \alpha$ and $E R \beta$ (Dahlman-Wright et al. 2006). ERs belong to the nuclear receptor family of ligandactivated transcription factors, and modulate the expression of target genes by binding either to classic estrogen response elements or to other transcription factors, which then bind to their respective response elements. The two ERs show overlapping, yet distinct, patterns of expression (DahlmanWright et al. 2006). Of particular relevance for glucose homeostasis, ER $\alpha$ is the major ER expressed in the liver (Kuiper et al. 1997), adipose tissue (Lundholm et al. 2004), skeletal muscle (Wiik et al. 2003), and pancreatic islets (Geisler et al. 2002). ER subtype-specific ligands have been developed, and are increasingly used to further clarify the specific roles of $E R \alpha$ and $E R \beta$ (Dahlman-Wright et al. 2006). For example, the $E R \alpha$-selective ligand propyl pyrazole triol (PPT) is 
reported to have a 410 -fold selectivity for $E R \alpha$ versus $E R \beta$ (Stauffer et al. 2000). An in vivo study using this compound shows effects similar to those of $E_{2}$, including increased uterine weight, and prevention of increased body weight and reduced bone mineral density normally associated with ovariectomy (Harris et al. 2002).

Estrogen deficiency also contributes to the development of obesity, insulin resistance, hyperglycemia, and type 2 diabetes in rodents (Louet et al. 2004). Accordingly, ovariectomy increased body weight, basal glucose levels and caused impaired glucose tolerance) in mice (Bailey \& Ahmed-Sorour 1980). Furthermore, aromatase knockout (ARKO) mice, which possess a genetic impairment in endogenous estrogen synthesis, exhibit decreased glucose tolerance, insulin resistance, and increased adiposity (Jones et al. 2000, Takeda et al. 2003). To investigate whether the above effects of estrogens are mediated via $E R \alpha$ or $E R \beta$, isoform-specific knockout animals were studied. These studies provided evidence that $E R \alpha$ knockout (ERKO) mice, but not $E R \beta$ knockout (BERKO) mice, exhibit metabolic effects similar to those observed in ovariectomized and ARKO mice, suggesting a critical role for $E R \alpha$ in the metabolic effects of estrogen (Heine et al. 2000).

We have recently demonstrated that glucose intolerance in ERKO mice is mainly due to hepatic insulin resistance, which was accompanied by the up-regulation of genes regulating fatty acid synthesis in the liver (Bryzgalova et al. 2006). Longterm treatment with $\mathrm{E}_{2}$ (30 days) improved glucose tolerance, insulin sensitivity and the insulin response to glucose in vivo in diabetic ob/ob mice (Gao et al. 2006). The expression of lipogenic genes in the livers of ob/ob mice was downregulated following estrogen treatment, and this was accompanied by reductions in liver TG levels (Gao et al. 2006). Additional studies demonstrated that the signal transducer and activator of transcription 3 (Stat3) could be a mediator of the effects of estrogen on lipogenic gene expression (Gao et al. 2006).

Our above studies in ERKO and ob/ob mice are consistent with a critical role for $E R \alpha$ in the estrogen-mediated improvement in glucose tolerance. The aim of the present study was to further investigate the molecular mechanisms behind the anti-diabetic effects of estrogens. For this purpose, we compared the molecular events associated with improved glucose tolerance in ob/ob mice following treatment with $\mathrm{E}_{2}$ and PPT.

\section{Materials and Methods}

\section{Animals}

All animal experiments were approved by the local ethical committees. $E_{2}$ was purchased from Sigma and was used as a reference substance. The ER $\alpha$-selective agonist PPT was obtained from Karo Bio (Huddinge, Sweden, 7 or 30 days treatment, single dose) or purchased from Tocris Bioscience
(Ellisville, MO, USA, 30 day multiple doses and 2-6h treatment). Three-month old female ob/ob mice bred in our own colony and in Umeå University, Sweden, were used for the experiments. Animals were treated subcutaneously either with $\mathrm{E}_{2}(0 \cdot 005,0 \cdot 05$, and $0 \cdot 1 \mathrm{mg} / \mathrm{kg}$ body weight per day $)$ or PPT $(0 \cdot 1,1 \cdot 0$, and $2 \cdot 5 \mathrm{mg} / \mathrm{kg}$ body weight per day) for 7-30 days. For the short-term study, female C57BL/6 mice were ovariectomized to remove the major site of endogenous estrogen synthesis at 10 weeks of age and killed at 14 weeks of age, 2,4 , or $6 \mathrm{~h}$ after a single treatment $(5 \mathrm{mg} / \mathrm{kg}$ body weight). Mice were injected subcutaneously. A group of ERKO mice and matched controls (obtained from Taconic, Ry, Denmark) were treated for 7 days with PPT $(1 \mathrm{mg} / \mathrm{kg}$, body weight). PPT was dissolved in 90\% sesame oil and 10\% ethanol, and control animals received vehicle. Blood was collected, centrifuged at $12000 \mathrm{~g}$ for $2 \mathrm{~min}$, and plasma was stored at $-20{ }^{\circ} \mathrm{C}$. Livers were collected and stored at $-80{ }^{\circ} \mathrm{C}$ for expression studies.

\section{Intraperitoneal glucose tolerance test (IPGTT)}

After 7-30 days of treatment, animals were fasted overnight and blood glucose levels were determined. The animals were administered with glucose solution $(2 \mathrm{~g} / \mathrm{kg}$ body weight) by i.p. injection, and blood glucose concentrations were measured at 10, 30, 60 and 120 min after glucose load. Blood glucose levels were measured using a MediSence glucose analyzer (Abbot Scandinavia AB).

\section{Intraperitoneal insulin tolerance test (IPITT)}

For IPITT experiments, blood glucose was measured in overnight fasted animals and insulin was injected at a dose of $0 \cdot 25 \mathrm{U} / \mathrm{kg}$ body weight. Ten minutes later, glucose was injected at a dose of $1 \mathrm{~g} / \mathrm{kg}$ body weight and blood glucose concentrations were measured at 15, 30, 60, 90, and $120 \mathrm{~min}$ after the glucose load.

\section{Insulin secretion in vitro}

Pancreatic islets were isolated by collagenase digestion (Khan et al. 1995). Groups of five islets were preincubated at $37^{\circ} \mathrm{C}$ for $1 \mathrm{~h}$ in Krebs-Ringer bicarbonate buffer (KRB), $\mathrm{pH} 7 \cdot 4$, containing $3.3 \mathrm{mmol} / 1$ glucose. The islets were then incubated in $\mathrm{KRB}$ for $1 \mathrm{~h}$ at $37^{\circ} \mathrm{C}$ with 3.3 or $16.7 \mathrm{mmol} / 1$ glucose, or with $3.3 \mathrm{mmol} / 1$ glucose and $20 \mathrm{mmol} / \mathrm{l}$ arginine. After incubation, the supernatants were stored at $-20{ }^{\circ} \mathrm{C}$ prior to insulin assay. Insulin was measured by RIA (Herbert et al. 1965).

\section{Glucose uptake in skeletal muscle}

Mice were anesthetized by i.p. injection of $2.5 \%$ avertin $(0.02 \mathrm{ml} / \mathrm{g}$ body weight $)$, and the extensor digitorum longus (EDL) and soleus muscles were removed for in vitro incubation. Isolated muscles were incubated for glucose 
uptake as described for the rat epitrochlearis muscle (Wallberg-Henriksson et al. 1987), in the absence or presence of insulin $(0 \cdot 18$ or $12 \mathrm{nM})$ for $30 \mathrm{~min}$. Glucose transport was assessed using 2-deoxyglucose (Hansen et al. 1995). Calculations included determination of the extracellular space and intracellular 2-deoxyglucose concentrations (Wallberg-Henriksson et al. 1987, Hansen et al. 1995). Glucose transport activity is expressed as $\mu \mathrm{mol} / \mathrm{ml} 2$-deoxyglucose per hour. A more detailed description of the method is given in the Supplementary Information.

\section{Glucose uptake in adipose tissue}

Adipocytes were isolated from mice by collagenase digestion as described (Arner \& Engfeldt 1987), and incubated at a concentration of $3.5 \%(\mathrm{vol} / \mathrm{vol})$ in KrebsRinger phosphate buffer ( $\mathrm{pH} 7 \cdot 4$ ) containing albumin $(40 \mathrm{mg} / \mathrm{ml}),\left(3{ }^{3} \mathrm{H}\right)$ glucose $\left(5 \times 10^{6}\right.$ c.p.m. $\left./ \mathrm{ml}\right)$, unlabelled glucose $(1 \mu \mathrm{mol} / \mathrm{l})$ and various concentrations of human insulin $\left(0,10^{-15}-10^{-6} \mathrm{M}\right)$. After $2 \mathrm{~h}$ at $37^{\circ} \mathrm{C}$ using air as the gas phase, incubations were stopped by rapidly chilling the incubation vials to $4{ }^{\circ} \mathrm{C}$ and adding $50 \mu \mathrm{l} 6 \mathrm{M} \mathrm{H}_{2} \mathrm{SO}_{4}$. Incorporation of radiolabeled glucose into adipocyte lipids was assayed.

Metabolonomics of lipid-soluble liver tissue extract using ${ }^{1} \mathrm{H}$ nuclear magnetic resonance (NMR) spectroscopy

Lipid-soluble liver tissue extracts were prepared and the amounts of lipids were analyzed using NMR spectroscopy, as described in the Supplementary Information.

\section{$R N A$ preparation and microarray analysis}

Total RNA was prepared from frozen tissue using TRIzol Reagent (Invitrogen) and purified using RNeasy Mini Kits (Qiagen). RNA quality was assayed using an Agilent 2100 Bioanalyzer (Agilent, Palo Alto, CA, USA). RNA was prepared for microarray analysis and hybridized to Mouse Genome 4302.0 arrays according to the Affymetrix GeneChip Expression Analysis manual (Affymetrix, Santa Clara, CA, USA). For the first set of microarray data (dataset I), RNA from each treatment group was pooled $(n=5)$ before preparation of probes. For the second set of microarray data (dataset II), RNA from individual mice $(n=3)$ was analyzed.

\section{Bioinformatics}

Output files from microarray analyses were analyzed using Affymetrix GeneChip operating software (GCOS). To assess differential gene expression between the PPT treatment and control groups, Affymetrix algorithms in GCOS was used for dataset I. For dataset II, the Bioconductor program (www.bioconductor.org) for $R$ was used with the Affymetrix linear modeling Graphical User Interface (affylmGUI) package (Wettenhall et al. 2006), which is based on linear models and empirical Bayes methods (Smyth 2004). Data were normalized using the robust multiarray average background correction method (Irizarry et al. 2003), and adjusted using the Benjamini \& Hochberg (1995) method for controlling false discovery rate. For Tables 2 and 3, only genes with reliable detection levels on all arrays (present) are included.

\section{Real-time PCR analysis}

RNA from individual animals was reverse transcribed into cDNA using Superscript II (Invitrogen) or Reverse Transcription Reagents (Applied Biosystems, Foster City, CA, USA) with random hexamer primers. Analyses were performed using a 7500 Fast Real-Time PCR System with Power SYBR Green Reagents (Applied Biosystems). PCR products were further analyzed by melting curve analysis to confirm single products. mRNA levels were normalized to hypoxanthine ribosyltransferase mRNA levels. Primer sequences are provided in the Supplementary Information.

\section{Western blot analysis}

Liver protein extracts were prepared and equal amounts of protein were separated by electrophoresis. Membranes were probed using Stat3 (Thermo Scientific, Cheshire, UK), phospho-Stat3 (Tyr705, Cell Signaling Technology, Danvers, MA, USA) and glucose-6-phosphatase (C-14, Santa Cruz Biotechnology, Santa Cruz, CA, USA) antibodies, and band densities were quantified using ImageJ (Rasband 1997-2007). A more detailed description of the method is given in the Supplementary Information.

\section{Statistical analysis}

Results are reported as mean \pm s.E.M. Statistical differences were determined by an unpaired Student's $t$-test (Figs 1, 3-6, 10 and 11) or one-way ANOVA (Kirkman 1996) followed by Fisher's least significant difference post hoc analysis (Figs 2, 7 and 9, Table 1). Statistical significance was accepted for $P<0 \cdot 05$. Statistical analyses for the microarray data are included in the Bioinformatics section.

\section{Results}

PPT improves glucose tolerance and decreases fasting blood glucose

$\mathrm{ob} / \mathrm{ob}$ mice were treated with PPT, $\mathrm{E}_{2}$ or vehicle. A treatment of 7 days with either PPT $(1 \mathrm{mg} / \mathrm{kg})$ or $\mathrm{E}_{2}(0.1 \mathrm{mg} / \mathrm{kg})$ had no effect on body weight when compared between treatment groups $(51.10 \pm 0.94 \mathrm{~g}, 51.66 \pm 0.89 \mathrm{~g}$, and $52.33 \pm 1.08 \mathrm{~g}$ for PPT, $E_{2}$, and vehicle treatment respectively). After overnight fasting, blood glucose concentrations were similar in mice treated for 7 days with vehicle, PPT or $\mathrm{E}_{2}$ (Fig. 1a). 

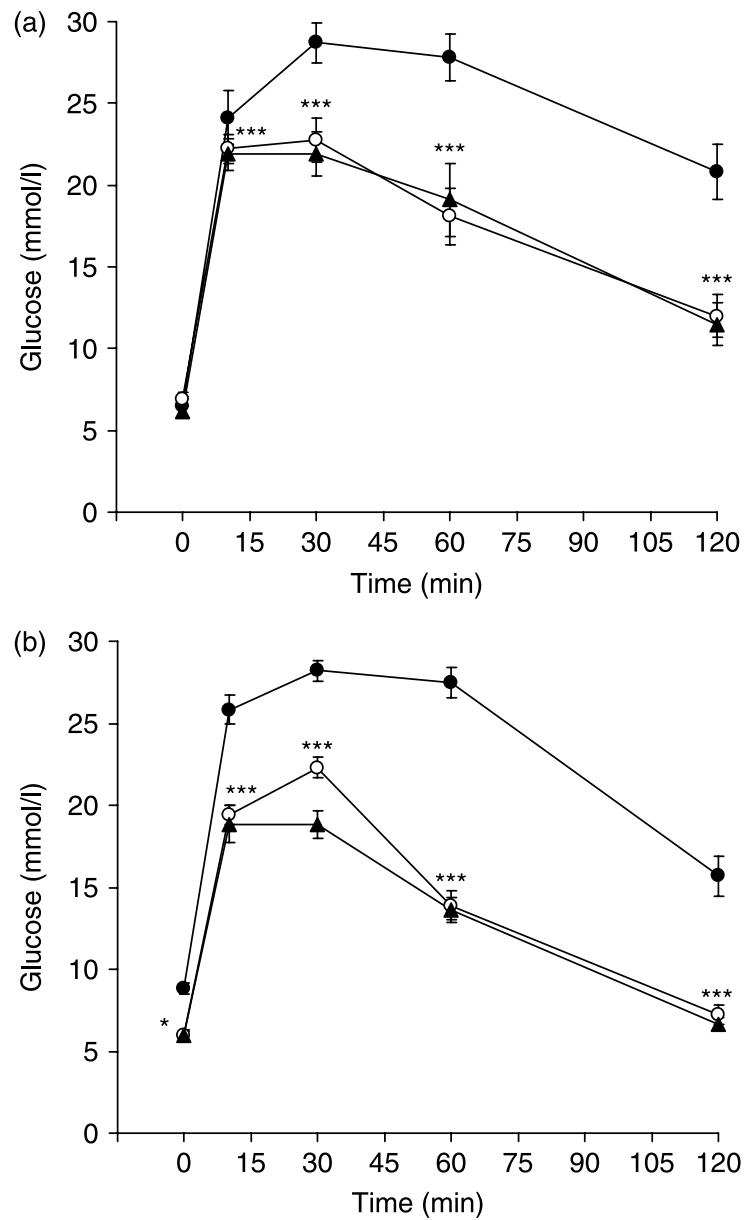

Figure 1 IPGTT was performed on overnight fasted ob/ob mice treated with either $E_{2}$ (open circle; $0.1 \mathrm{mg} / \mathrm{kg}$ body weight), PPT (filled triangle; $1 \mathrm{mg} / \mathrm{kg}$ body weight) or vehicle (filled circle) for (a) 7 days $(n=9)$ or (b) 30 days $(n=7-8)$. Blood glucose concentrations were measured at the basal state and after glucose load (2 g/kg, i.p.) at the indicated time points. Data are presented as mean \pm S.E.M. ${ }^{*} P<0 \cdot 05,{ }^{* * *} P<0 \cdot 001$ versus vehicle-treated ob/ob mice.

IPGTT, however, revealed that PPT and $\mathrm{E}_{2}$ markedly improved glucose tolerance. To investigate whether longterm treatment alters basal glucose levels, ob/ob mice were treated for 30 days with the same doses of PPT or $\mathrm{E}_{2}$. Fasting blood glucose was significantly decreased in PPT and $\mathrm{E}_{2^{-}}$ treated animals, and glucose tolerance was markedly improved (Fig. 1b). A tendency toward increased body weight during the course of the experiment in vehicle-treated animals was not seen in $E_{2}$-treated animals (Table 1). However, this did not reach statistical significance.

To investigate the dose-response of the observed effects of PPT, ob/ob mice were treated with PPT at different concentrations for 30 days. Basal blood glucose concentrations were significantly decreased in animals treated with $0 \cdot 1,1 \cdot 0$, or $2 \cdot 5 \mathrm{mg} / \mathrm{kg}$ of PPT (Fig. 2a), while glucose tolerance was significantly improved at doses of 1.0 and $2.5 \mathrm{mg} / \mathrm{kg}$ PPT. At doses of $0 \cdot 005,0 \cdot 05$, and $0.1 \mathrm{mg} / \mathrm{kg}, \mathrm{E}_{2}$
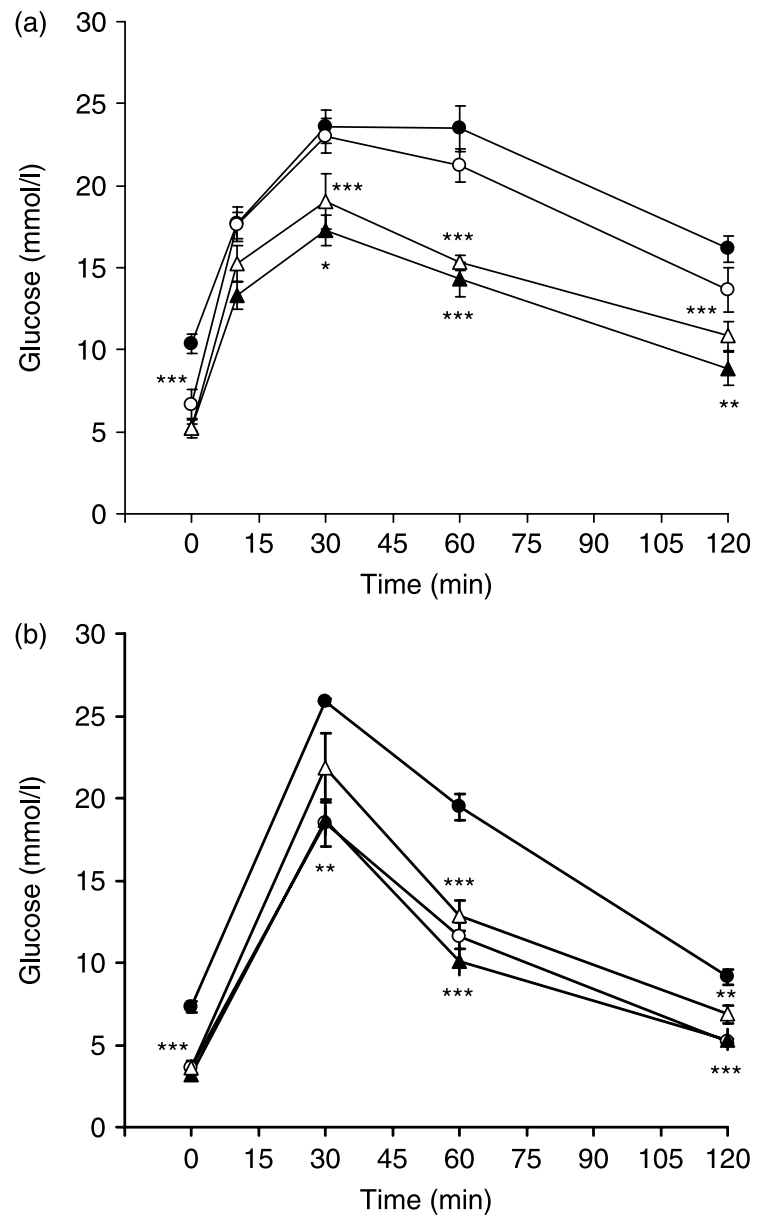

Figure 2 (a) Effect of different doses of PPT on glucose tolerance in $\mathrm{ob} / \mathrm{ob}$ mice. IPGTT was conducted after daily treatment with PPT for 30 days. Doses of PPT: $0.1 \mathrm{mg} / \mathrm{kg}$ (open circle), $1.0 \mathrm{mg} / \mathrm{kg}$ (open triangle), $2.5 \mathrm{mg} / \mathrm{kg}$ (filled triangle), and vehicle (filled circle). Data are presented as mean \pm S.E.M. for groups of 5-6 mice. ${ }^{*} P<0 \cdot 05,{ }^{* *} P<0 \cdot 01,{ }^{* * *} P<0 \cdot 001$ versus vehicle-treated ob/ob mice. (b) Effect of different doses of $E_{2}$ on glucose tolerance in ob/ob mice. IPGTT was performed after daily treatment with $E_{2}$ for 30 days. Doses of $\mathrm{E}_{2}: 0.005 \mathrm{mg} / \mathrm{kg}$ (open triangle), $0.05 \mathrm{mg} / \mathrm{kg}$ (open circle), $0 \cdot 1 \mathrm{mg} / \mathrm{kg}$ (filled triangle) and vehicle (filled circle). Data are presented as mean \pm S.E.M. for groups of 4-5 mice. ${ }^{* *} P<0 \cdot 01,{ }^{* * *} P<0 \cdot 001$ versus vehicle-treated ob/ob mice.

similarly improved fasting blood glucose levels and glucose tolerance after 30 days of treatment (Fig. 2b).

\section{PPT improves insulin sensitivity}

In the insulin tolerance test, fasting blood glucose levels were similar in control, PPT- and $\mathrm{E}_{2}$-treated mice after 7 days (Fig. 3a). Blood glucose concentrations increased in all mice after the glucose challenge (15 $\mathrm{min})$, although the increase in blood glucose was significantly less in PPT and $E_{2}$-treated mice. Blood glucose concentrations then gradually dropped in all groups and were significantly lower in PPT and 
Table 1 Body weights (mean \pm s.E.M.) in ob/ob mice after 30 days of treatment with vehicle, $17 \beta$-estradiol $\left(\mathrm{E}_{2} ; 0 \cdot 1 \mathrm{mg} / \mathrm{kg}\right.$ body weight) and propyl pyrazole triol (PPT; $1 \mathrm{mg} / \mathrm{kg}$ body weight)

\begin{tabular}{|c|c|c|c|}
\hline & $\begin{array}{l}\text { Before } \\
\text { treatment }(\mathrm{g})\end{array}$ & $\begin{array}{l}\text { After } \\
\text { treatment }(\mathrm{g})\end{array}$ & $P$ value \\
\hline \multicolumn{4}{|c|}{ Treatment group } \\
\hline Vehicle & $49 \cdot 27 \pm 0 \cdot 7$ & $52 \cdot 00 \pm 1 \cdot 64$ & \\
\hline $\mathrm{E}_{2}$ & $49 \cdot 25 \pm 1 \cdot 13$ & $49 \cdot 00 \pm 0.96$ & NS \\
\hline PPT & $50 \cdot 00 \pm 1 \cdot 40$ & $51 \cdot 38 \pm 1 \cdot 42$ & NS \\
\hline
\end{tabular}

Data are presented as means \pm s.E.M.; for all groups, $n=7-8$.

$\mathrm{E}_{2}$-treated mice, compared with control mice, at the 60, 90, and 120 min time points.

Thirty days' treatment of ob/ob mice with either PPT or $\mathrm{E}_{2}$ significantly decreased fasting blood glucose levels (Fig. 3b). Blood glucose levels were then significantly reduced
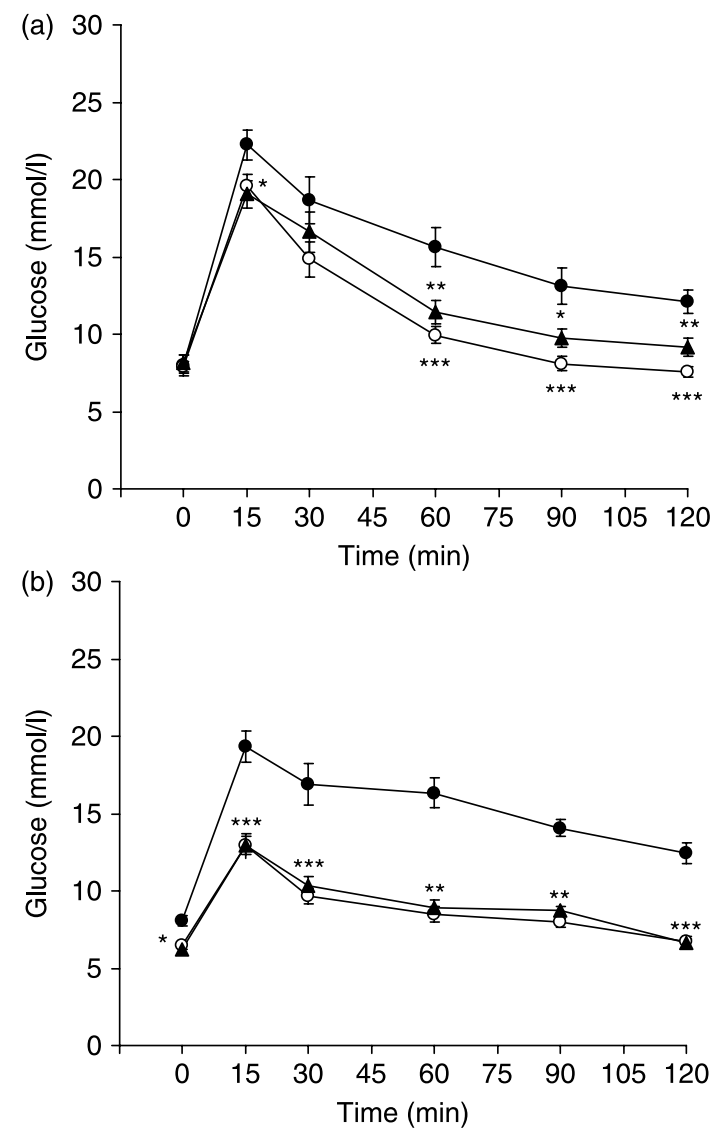

Figure 3 IPITT was performed in overnight fasted ob/ob mice treated with either $E_{2}$ (open circle; $0 \cdot 1 \mathrm{mg} / \mathrm{kg}$ body weight), PPT (triangle; $1 \mathrm{mg} / \mathrm{kg}$ body weight), or vehicle (filled circle) for (a) 7 days $(n=9)$ or (b) 30 days $(n=7-8)$. Mice were injected first with insulin at a dose of $0.25 \mathrm{U} / \mathrm{kg}$, i.p., and $10 \mathrm{~min}$ later with glucose at the dose $1 \mathrm{~g} / \mathrm{kg}$ i.p. Blood glucose concentrations were measured at the basal condition, and at different time points after the glucose load. Data are presented as mean \pm S.E.M. ${ }^{*} P<0 \cdot 05,{ }^{*} P<0 \cdot 01$, $* * * P<0 \cdot 001$ versus vehicle-treated ob/ob mice. throughout the experiment in mice treated with either PPT or $\mathrm{E}_{2}$, compared with mice treated with vehicle (Fig. 3b).

\section{The effect of PPT is mediated via $E R \alpha$}

Seven days of PPT treatment $(1 \mathrm{mg} / \mathrm{kg}$ body weight) in ERKO mice had no effect on either glucose tolerance (Fig. 4a) or insulin sensitivity (Fig. 4b), as measured using IPGTT and IPITT respectively. PPT also had no effect in control mice.

Skeletal muscle and adipose tissue glucose uptake is unaltered by PPT treatment

Seven days of PPT treatment $(1 \mathrm{mg} / \mathrm{kg})$ was without effect on basal glucose uptake in the skeletal muscle in ob/ob mice
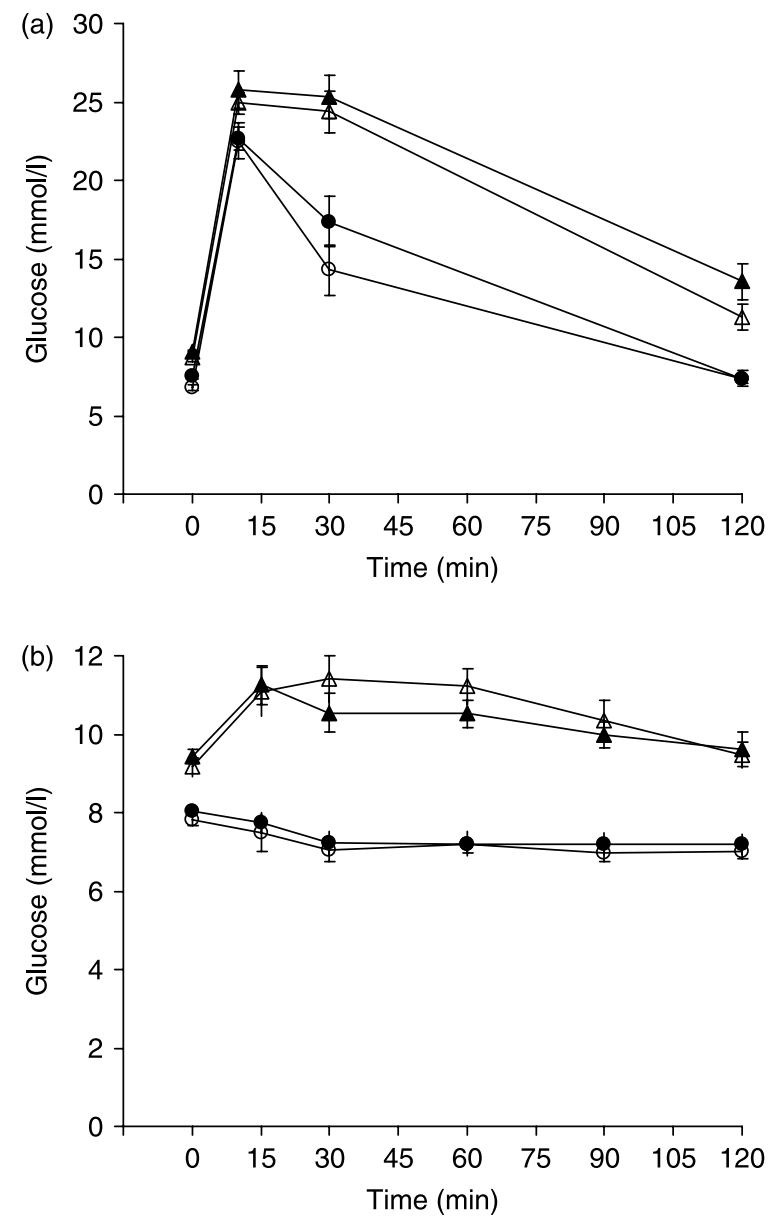

Figure 4 (a) IPGTT and (b) IPITT in overnight fasted ERKO (triangles) and control (circles) mice treated with vehicle (open circles and triangles) or PPT (1.0 mg/kg body weight; filled circles and triangles) for 7 days. Blood glucose concentrations were measured at the basal state and after glucose load ( $2 \mathrm{~g} / \mathrm{kg}$, i.p.) at the indicated time points. Data are presented as mean \pm s.E.M. For IPITT, mice were injected first with insulin at a dose of $0 \cdot 25 \mathrm{U} / \mathrm{kg}$, i.p., and $10 \mathrm{~min}$ later with glucose at the dose $1 \mathrm{~g} / \mathrm{kg}$ i.p. Blood glucose concentrations were measured at the basal condition, and at different time points after the glucose load. Data are presented as mean \pm s.E.M. 

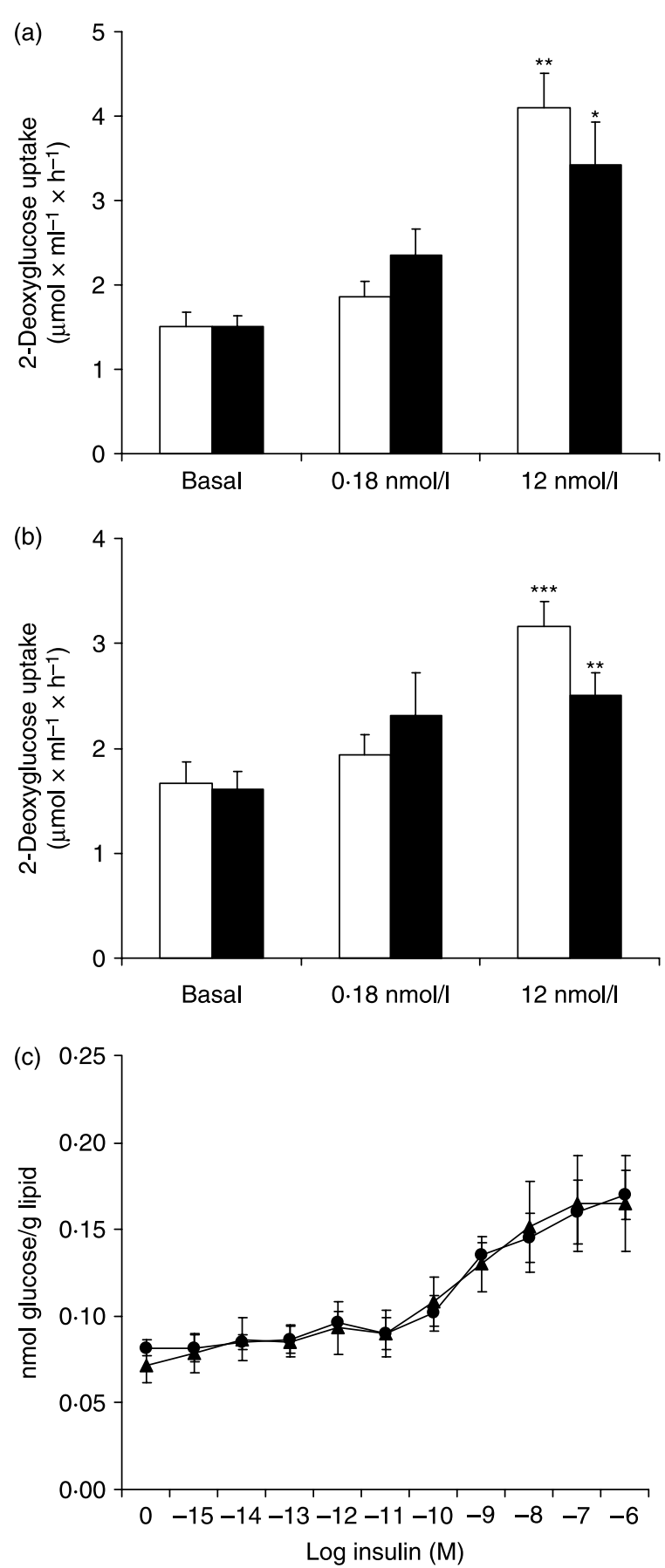

Figure 5 Glucose uptake in skeletal muscle or adipose tissue. (a) Isolated soleus or (b) EDL muscles from ob/ob mice treated with vehicle (open bar) or PPT (filled bar) for 7 days were incubated for $30 \mathrm{~min}$ in the absence or presence of insulin $(0.18$ or $12 \mathrm{nmol} / \mathrm{l})$, and glucose uptake was determined. Data are presented as mean \pm S.E.M., $n=5-7 . * P<0 \cdot 05,{ }^{* *} P<0 \cdot 01,{ }^{* * *} P<0 \cdot 001$ versus basal levels (no insulin). (c) Glucose uptake in adipose tissue from PPT (triangle) or vehicle-treated (circle) ob/ob mice for 30 days, expressed as nmol glucose incorporated into lipids per g lipid. Data are presented as mean \pm S.E.M., $n=6$.
(Fig. 5a and b). Insulin (12 nmol/l) increased 2-deoxyglucose uptake in the soleus and EDL skeletal muscles, but PPT treatment did not affect insulin-stimulated glucose uptake. Furthermore, glucose uptake in adipose tissue was unchanged after 30 days of PPT treatment (Fig. 5c).

\section{Preserved B-cell secretory capacity after PPT treatment}

Glucose $(16.7 \mathrm{mM})$ induced insulin secretion in isolated islets from both control and PPT-treated ob/ob mice, compared with the basal state $(3.3 \mathrm{mM})$, with no difference between the groups (Fig. 6). Arginine-induced insulin secretion was also similar between control and PPT-treated animals.

\section{Differential effects of PPT and $E_{2}$ on hepatic lipid profiles}

We have previously reported that treatment of ob/ob mice with $\mathrm{E}_{2}$ decreases liver TGs. NMR analyses of lipid extracts from the livers of ob/ob mice treated with PPT at $0 \cdot 1,1 \cdot 0$, and $2.5 \mathrm{mg} / \mathrm{kg}$ for 30 days showed no significant effects on total lipids, TGs or cholesterol, while treatment of animals with $\mathrm{E}_{2}$ at $0 \cdot 005,0 \cdot 05$, and $0 \cdot 1 \mathrm{mg} / \mathrm{kg}$ significantly decreased total lipid, TG, and cholesterol levels (Fig. 7).

\section{Identification of ER $\alpha$ target genes in the liver; comparing the} effects of PPT and $E_{2}$

To further characterize the molecular effects of PPT in ob/ob mice, we performed gene expression profiling experiments on livers from PPT- $(0 \cdot 1,1 \cdot 0$, and $2 \cdot 5 \mathrm{mg} / \mathrm{kg})$ and vehicle-treated animals (dataset I), with the ultimate goal of comparing these gene expression profiles with those of $\mathrm{E}_{2}$-treated animals. Expression profiling was conducted at each dose since the absorption, distribution, metabolism, and excretion properties

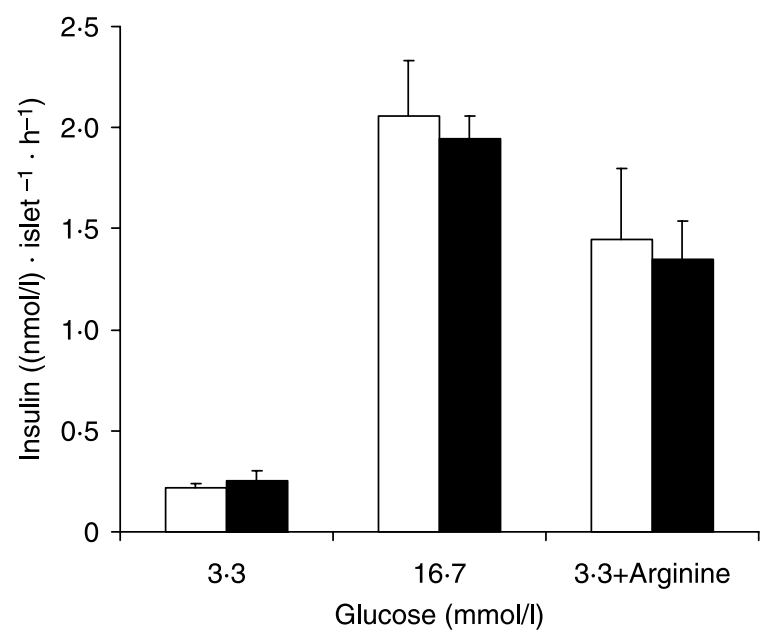

Figure 6 Insulin secretion in batch-incubated islets isolated from ob/ob mice treated with PPT (filled bar) or vehicle (open bar) for 30 days. Islets were incubated at different glucose concentrations and in the presence of arginine. Data are presented as mean \pm S.E.M. for groups of 5-6 mice. 

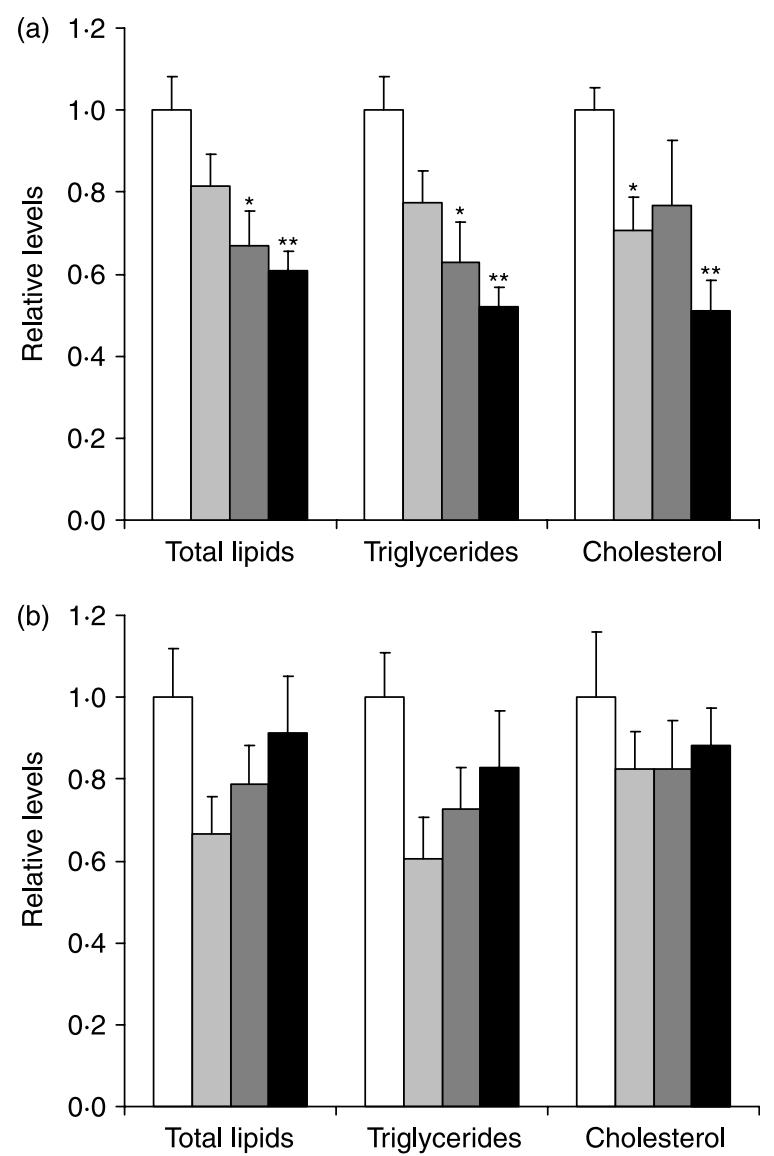

Figure 7 Treatment with (a) $E_{2}$, but not (b) PPT, significantly decreases hepatic lipids as determined by NMR analysis on lipid extracts $(n=4-5)$. Doses of $\mathrm{E}_{2}: 0.005 \mathrm{mg} / \mathrm{kg}$ (light grey bar), $0.05 \mathrm{mg} / \mathrm{kg}$ (dark grey bar), $0 \cdot 1 \mathrm{mg} / \mathrm{kg}$ (black bar), and vehicle (white bar). Values are expressed as mean \pm s.E.M. ${ }^{*} P<0 \cdot 05$, $* * P<0.01$ versus vehicle-treated ob/ob mice. Doses of PPT: $0.1 \mathrm{mg} / \mathrm{kg}$ (light grey bar), $1.0 \mathrm{mg} / \mathrm{kg}$ (dark grey bar), $2.5 \mathrm{mg} / \mathrm{kg}$ (black bar) and vehicle (white bar).

are poorly defined for this compound. Gene expression profiling for all PPT dose groups was initially carried out with pooled RNA. The number of regulated genes increased with dose (Fig. $8 \mathrm{a}$ and b). After treatment with $0 \cdot 1,1 \cdot 0$, and $2 \cdot 5 \mathrm{mg}$ $\mathrm{PPT} / \mathrm{kg}$ body weight, there were 490, 1364, and 1897 increased genes, and 502,1482, and 1583 decreased genes respectively compared with vehicle. 140 increased and 226 decreased genes were regulated at all investigated doses of PPT treatment (Supplementary Table 1, see Supplementary data in the online of version of the Journal of Endocrinology at http:// joe.endocrinology-journals.org/content/vol199/issue2/), and there was a dose-dependent increase in the average foldchange for regulated genes (Fig. 8c).

Real-time PCR was used to confirm the changes in expression of several genes that were identified by the microarray analysis. Stat 3 and $E R \alpha$ were among the genes that were increased by PPT, whilst the decreased genes included glucose6-phosphatase, catalytic (G6pc), CCAAT/enhancer-binding

(a)

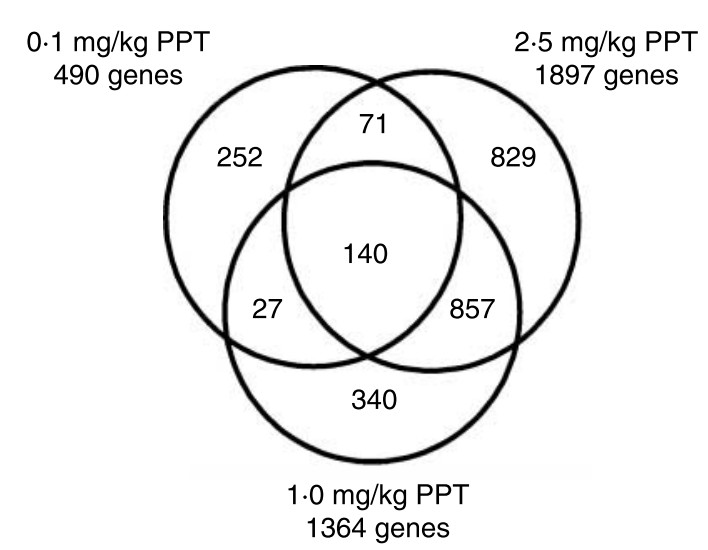

(b)

Decreased genes

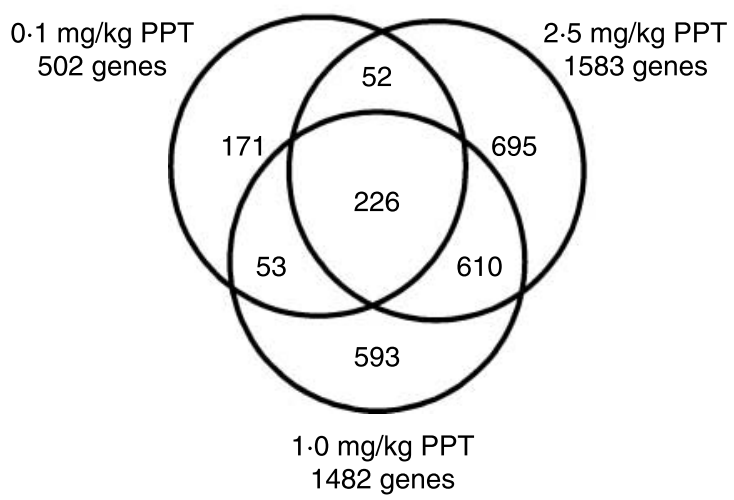

(c)

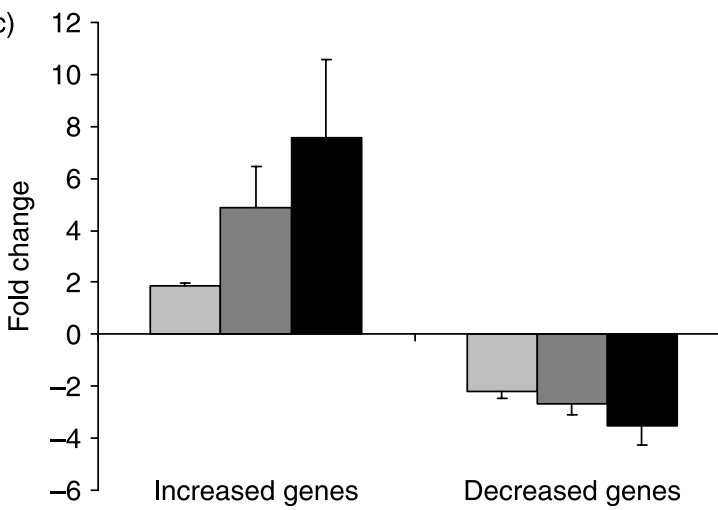

Figure 8 ( $a$ and b) Dose-dependent increase in both the number of genes regulated by PPT and (c) the fold changes at the different doses, for dataset I. ( $a$ and $b$ ) Venn diagram of the number of increased and decreased genes identified by Affymetrix microarray after treatment with $0 \cdot 1,1 \cdot 0$, and $2.5 \mathrm{mg} / \mathrm{kg}$ PPT compared with vehicle control, using pooled RNA. (c) The fold changes for all genes co-regulated by PPT $(140 ; 226)$ are displayed as mean \pm S.E.M. for each dose (compared with vehicle). $0.1 \mathrm{mg} / \mathrm{kg}$ (light grey bar), $1.0 \mathrm{mg} / \mathrm{kg}$ (dark grey bar) and $2.5 \mathrm{mg} / \mathrm{kg}$ (black bar). 
protein $\beta(C e b p b)$, Krüppel-like factor 15 (Klf15), glucose transporter 1 (Glut1, also called SLC2A1), and very low density lipoprotein receptor (Fig. 9).

By comparing the genes identified as being regulated by $\mathrm{E}_{2}$ from our previous study with those regulated by all doses of PPT (Table 2), we identified gene expression changes that are common to $\mathrm{E}_{2}$ and PPT treatment. Included among these changes are the up-regulation of Stat3 and the downregulation of $G 6 p c$.

To confirm the gene expression profiles found in pooled liver RNA samples, and to facilitate comparison with previous gene expression profiling experiments in $E_{2}$-treated $\mathrm{ob} / \mathrm{ob}$ mice in which individual animals were assayed, livers from individual animals treated with PPT $(1 \mathrm{mg} / \mathrm{kg})$ were analyzed (dataset II). The gene expression changes shown in Table 3 are conserved between $\mathrm{E}_{2}$ and PPT treatment, using a filter of a two-fold change to identify differentiallyexpressed genes. Again, G6pc is identified as a gene that is consistently down-regulated after PPT and $\mathrm{E}_{2}$ treatment. The complete list of genes significantly regulated by PPT at $1 \mathrm{mg} / \mathrm{kg}$ is included in Supplementary Table 2, see Supplementary data in the online of version of the Journal of Endocrinology at http://joe.endocrinology-journals.org/ content/vol199/issue2/.

\section{Changes in Stat3 and G6pc $m R N A$ levels were accompanied by} changes in Stat3 and G6pc protein levels

The induction of Stat3 protein and of activated, phosphorylated Stat3 protein (Fig. 10a) were demonstrated in the livers of $\mathrm{ob} / \mathrm{ob}$ mice after 30 days of PPT treatment $(1 \mathrm{mg} / \mathrm{kg})$, though the induction of Stat 3 protein did not quite reach statistical significance (Fig. 10b). For glucose-6-phosphatase, a decrease in protein levels was demonstrated (Fig. 10a and b).

\section{G6pc and Stat3 are ER $\alpha$ target genes in liver}

To investigate whether G6pc and Stat3 represent direct target genes for PPT, we assayed their expression after short-term PPT treatment in ovariectomized mice. The mRNA for G6pc was significantly decreased after $6 \mathrm{~h}$ of PPT treatment (Fig. 11a). The expression of Stat3 was significantly increased from $4 \mathrm{~h}$ of PPT treatment (Fig. 11b).

\section{Discussion}

In the present study we used leptin-deficient ob/ob mice, an animal model of type 2 diabetes. ob/ob mice become hyperglycemic and hyperinsulinemic from the age of 1-2 months, at which point body weight also starts to increase, compared with wild-type animals (Westman 1968). At 5-6 months of age, the animals reach maximum body weight, which remains stable until 13-17 months of age (Westman 1968). Hyperglycemia and hyperinsulinemia also increase with age, and the highest mean blood glucose and insulin values are obtained in 4-6 month old animals.

We have shown that treatment of 3-month-old female $\mathrm{ob} / \mathrm{ob}$ mice with $\mathrm{E}_{2}$ for 30 days significantly decreased basal blood glucose levels and improved glucose tolerance and

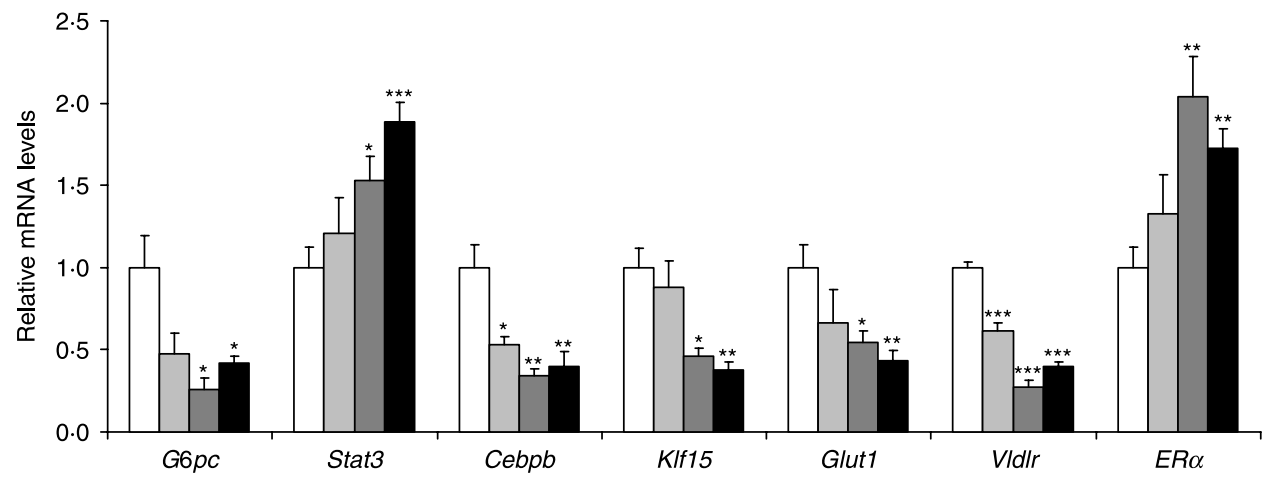

\begin{tabular}{cccccccc}
\hline Fold change versus vehicle & G6pc & Stat3 & Cebpb & Klf15 & Glut1 & Vldlr & ER $\alpha$ \\
\hline $0.1 \mathrm{mg} / \mathrm{kg}$ PPT & -1.5 & 1.2 & $-1.9 ;-1.6$ & -1.2 & -1.3 & -1.2 & $1.5 ; 1.4$ \\
$1.0 \mathrm{mg} / \mathrm{kg}$ PPT & -1.5 & 1.3 & $-1.3 ;-1.2$ & -2.0 & -1.7 & -2.8 & $1.7 ; 1.9$ \\
$2.5 \mathrm{mg} / \mathrm{kg}$ PPT & -1.7 & 1.3 & $-1.9 ;-1.5$ & -2.8 & -2.5 & -2.6 & $1.5 ; 1.7$ \\
\hline
\end{tabular}

Figure $9 \mathrm{mRNA}$ levels of genes regulated by $0 \cdot 1,1 \cdot 0$, and $2.5 \mathrm{mg} / \mathrm{kg}$ PPT treatment in the gene expression profiling experiment were confirmed by real-time PCR in individual animals $(n=5) .0 .1 \mathrm{mg} / \mathrm{kg}$ (light grey bar), $1.0 \mathrm{mg} / \mathrm{kg}$ (dark grey bar), $2.5 \mathrm{mg} / \mathrm{kg}$ (black bar) and vehicle (white bar). Fold changes from microarray data are tabulated below the figure (two probe sets of $C e b p b$ and $E R \alpha$ were regulated). Abbreviations used: glucose-6-phosphatase, catalytic $(G 6 p c)$, signal transducer and activator of transcription 3 (Stat3), CCAAT/enhancer-binding protein $\beta$ (Cebpb), Krüppel-like factor 15 (Klf15), glucose transporter 1 (Glut1) and very low density lipoprotein receptor $(V I d I r)$. Data are presented as mean \pm s.E.M. ${ }^{*} P<0 \cdot 05, * * P<0 \cdot 01$, $* * * P<0 \cdot 001$ versus vehicle-treated ob/ob mice. 
Table 2 Genes co-regulated by propyl pyrazole triol (PPT) and $17 \beta$-estradiol $\left(E_{2}\right)$ treatment $(I)$. Glucose-6-phosphatase, catalytic (G6pc) and signal transducer and activator of transcription 3 (Stat3) are identified as co-regulated by $E_{2}$ and PPT treatment. The PPT data are from dataset $\mathrm{I}$, using genes co-regulated at all PPT doses

\section{Increased by PPT and $E_{2}$}

CD163 antigen

Cysteine sulfinic acid decarboxylase

DNase II $\alpha$

Fibronectin 1

Orosomucoid 2

Signal transducer and activator of transcription 3

Solute carrier family 3 , member 1

Suppressor of cytokine signaling 2

Syndecan 4

\section{Decreased by PPT and $E_{2}$}

Butyrylcholinesterase

Esterase 22

Fatty acid desaturase 2

Glucose-6-phosphatase, catalytic

Glutamate-cysteine ligase, catalytic subunit

Glutathione S-transferase, $\alpha 2$ (Yc2)

Lectin, galactose binding, soluble 1

Microsomal glutathione S-transferase 3

Pituitary tumor-transforming 1

Protein phosphatase $1 \mathrm{~B}$, magnesium dependent, $\beta$ isoform

Serum/glucocorticoid regulated kinase 2

insulin sensitivity (Gao et al. 2006). The insulin response to glucose in vivo was also significantly improved. In this study, we demonstrate that glucose tolerance and insulin sensitivity are significantly improved in ob/ob mice from 7 days of treatment with $E_{2}$, which confirms the strong anti-diabetic effect of estrogens.

Chronic estrogen treatment has been shown to decrease food intake and body weight in rodents (Alonso et al. 2006,

Table 3 Genes co-regulated by propyl pyrazole triol (PPT) and $17 \beta$-estradiol $\left(\mathrm{E}_{2}\right)$ treatment (II). Glucose-6-phosphatase, catalytic $(G 6 p c)$ is identified as co-regulated by PPT and $\mathrm{E}_{2}$ treatment. The PPT data are from dataset II. The experimental setup, analysis, and threshold (two-fold) are equal for the PPT and $E_{2}$ experiment

\section{Increased by PPT and $E_{2}$}

Cadherin 1

CD163 antigen

Cysteine sulfinic acid decarboxylase

Solute carrier family 3 , member 1

Suppressor of cytokine signaling 2

\section{Decreased by PPT and $E_{2}$}

Carbonic anhydrase 3

Fatty acid desaturase 2

Glucose-6-phosphatase, catalytic

Glutathione S-transferase, $\alpha 2$ (Yc2)

Plasma membrane associated protein, S3-12 (a)
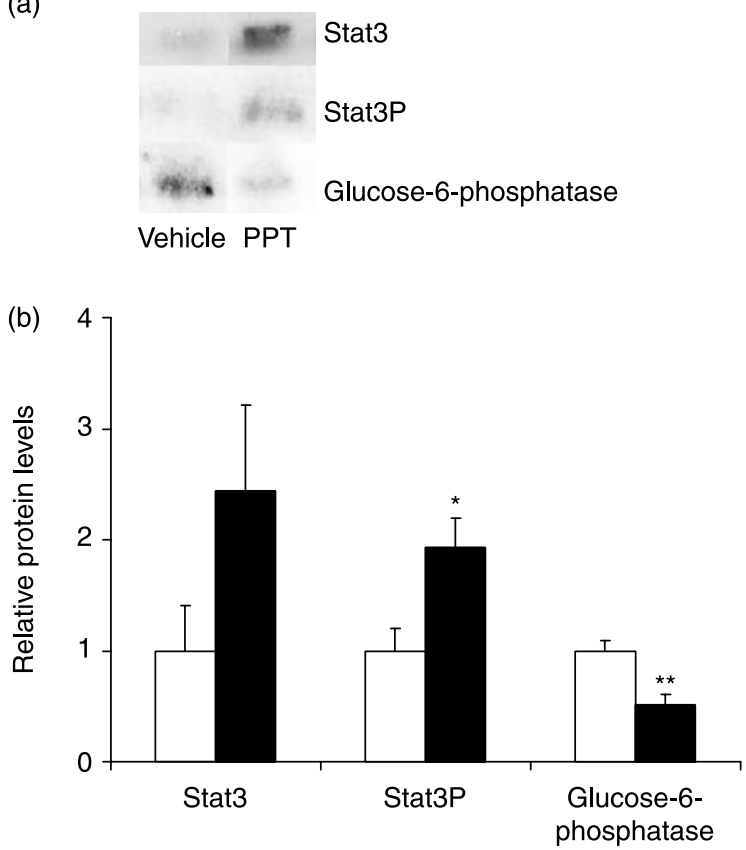

Figure 10 Western blot analysis of Stat3, phosphorylated Stat3, and glucose-6-phosphatase. A representative sample is shown from (a) one PPT-treated and one vehicle-treated liver, together with (b) the average densities for each protein $(n=5)$. Ob/ob mice were treated with PPT (filled bar) or vehicle (open bar) for 30 days.

Clegg et al. 2006, Roesch 2006, Gao et al. 2007, Wegorzewska et al. 2008). In the present study, $\mathrm{E}_{2}$-treated animals did not exhibit the trend toward increased body weight that was seen in controls, although we could not demonstrate a statistical difference in body weight between these groups. However, caution should be employed when making direct comparisons between this and previous studies in this respect, since the effect of $E_{2}$ on body weight could depend upon factors such as the dose of $E_{2}$, its route of administration, and the animal model used. For example, reduced weight gain was observed in $\mathrm{ob} / \mathrm{ob}$ and $\mathrm{db} / \mathrm{db}$ mice treated with $\mathrm{E}_{2}$ for 4 weeks by s.c. intrascapular capsule implants (Gao et al. 2007). However, neither the dose of $E_{2}$ nor its circulating levels are discussed in this article, although the latter is described to be high, and so a comparison with the current study is difficult. Decreases in weight gain have also been reported in $\mathrm{E}_{2}$-treated ovariectomized rats with normal leptin signaling (Alonso et al. 2006, Clegg et al. 2006, Roesch 2006, Wegorzewska et al. 2008). In this study, we have treated leptin-deficient female ob/ob mice with s.c. $\mathrm{E}_{2}$ doses that are either comparable or less than those used in the above reports, after normalizing $\mathrm{E}_{2}$ dose for body weight.

The effects that we observe on glucose tolerance and insulin sensitivity following $\mathrm{E}_{2}$ treatment are mediated via $E R \alpha$, since PPT has effects similar to $E_{2}$ on glucose metabolism. To further investigate the selectivity of PPT as an ER $\alpha$-agonist, we treated 

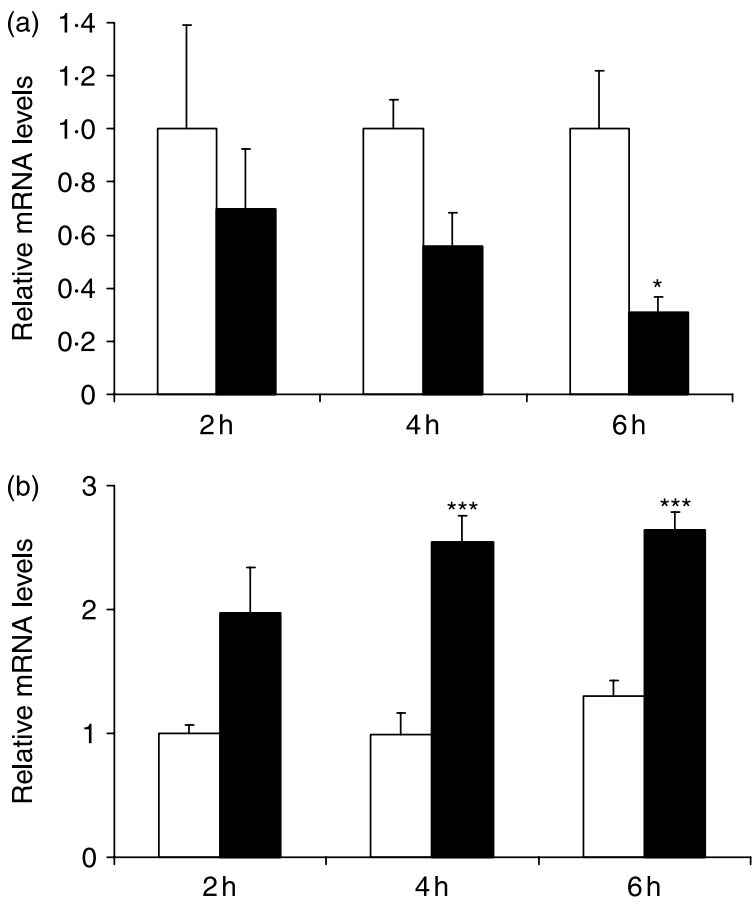

Figure 11 (a) G6pc mRNA was decreased by PPT after $6 \mathrm{~h}$ treatment, with a trend towards a change also at earlier time points. (b) Stat 3 mRNA was significantly increased after $4 \mathrm{~h}$ of PPT treatment. Open bar, vehicle; filled bar, PPT. Data are presented as mean \pm S.E.M. ${ }^{*} P<0 \cdot 05,{ }^{* *} P<0 \cdot 01, * * * P<0 \cdot 001$ versus vehicletreated ob/ob mice.

ERKO mice with PPT for 7 days and then performed glucose and insulin tolerance tests. As expected, PPT had no effect on glucose or insulin tolerance in ERKO mice, showing that PPT works as an ER $\boldsymbol{\alpha}$-selective agonist.

In ob/ob mice, the effect of PPT was dose- and time dependent. Thus, while seven days' treatment with PPT improved glucose tolerance without decreasing the fasting blood glucose level, treatment of ob/ob mice for 30 days significantly decreased fasting blood glucose and improved glucose tolerance. The present data are consistent with reports suggesting a critical role for $E R \alpha$ in glucose control (Heine et al. 2000, Bryzgalova et al. 2006).

We have previously proposed that hyperglycemia, hyperinsulinaemia, and insulin resistance in ERKO mice are mainly due to impaired insulin sensitivity in the liver (Bryzgalova et al. 2006). Therefore, the improved glucose metabolism in $\mathrm{ob} / \mathrm{ob}$ mice treated with PPT is likely to occur as a consequence of improved hepatic insulin sensitivity in these animals. This notion is supported by our findings that basal and insulin-mediated glucose uptake in skeletal muscle and adipose tissue of PPT-treated mice were similar to vehicletreated mice. In addition, the secretory capacity of pancreatic islets was unchanged after PPT treatment.

In contrast to $E_{2}$-treated mice, the hepatic lipid content of PPT-treated mice was unchanged. Furthermore, the expression of lipogenic genes (eg stearoyl-coenzyme A desaturase 1 and fatty acid synthase, data not shown) was not significantly reduced in PPT-treated mice, as previously reported for $\mathrm{E}_{2}$-treated mice (Gao et al. 2006). This suggests that the regulation of lipid metabolism may not be critical for PPT-mediated improvements in glucose tolerance and insulin sensitivity.

To study the molecular mechanisms behind the antidiabetic effect of estrogens, we have analyzed genome-wide expression profiles in the liver from PPT-treated versus vehicle-treated mice. The PPT doses were selected based on previous in vivo studies (Lai et al. 2003). Our study demonstrated a dose-dependent increase in the number of changed genes. We focused on genes that were co-regulated in ob/ob mice upon $\mathrm{E}_{2}$ and PPT treatment respectively. Importantly, the expression of Stat 3 was increased by both $\mathrm{E}_{2}$ and PPT (Table 2). In addition, we show that the protein expression and activity of Stat 3 were induced after PPT treatment, in accordance with previous data in $\mathrm{E}_{2}$-treated $\mathrm{ob} / \mathrm{ob}$ mice (Gao et al. 2006). Liver-specific deficiency of Stat 3 leads to insulin resistance in mice, whereas the activation of Stat 3 signaling by expression of a constitutively active form of Stat3 in the liver improves glucose tolerance and insulin resistance in diabetic $\mathrm{db} / \mathrm{db}$ mice (Inoue et al. 2004). Accordingly, we have previously proposed that increased expression of Stat3 in the liver of ob/ob mice upon $\mathrm{E}_{2}$ treatment is a potential mediator of the effects of $E_{2}$ in enhancing hepatic insulin sensitivity (Gao et al. 2006). Stat3, included in Table 2, is not identified in Table 3 as a gene co-regulated by PPT and $E_{2}$. This probably reflects the fact that levels of Stat3 expression varies between individuals. In our experience, individual variation within groups must be relatively small in order to obtain significance with methods like affylmGUI, which was used to identify regulated genes as input for this table. Stat 3 was significantly $(P<0 \cdot 05)$ regulated by PPT when assayed by real-time PCR (Fig. 9, $n=5$ ).

A gene co-ordinately decreased by both $\mathrm{E}_{2}$ and PPT treatment was G6pc. The expression of G6pc is high in diabetic animals and contributes to the development of hyperglycemia (Trinh et al. 1998). Over-expression of G6pc in cultured hepatocytes and in rats in vivo results in increased glucose production (Seoane et al. 1997, Trinh et al. 1998). Therefore, decreased expression of G6pc due to PPT and $\mathrm{E}_{2}$ treatment may contribute to the decreased fasting blood glucose levels observed in animals treated with PPT. Two earlier studies in $\mathrm{ob} / \mathrm{ob}$ mice and aging rats provide evidence for decreased glucose-6-phosphatase activity after estrogen treatment (Borthwick et al. 2001, Moorthy et al. 2004). Interestingly, using the ChIP-on-chip assay, we identified functional binding sites for ER $\alpha$ that could mediate direct regulation around the transcription start site (at -4548 and +208 ) of the G6pc gene (Gao et al. 2008). In parallel with STAT-3 and G6Pase, the expression of a number of other genes was altered by PPT treatment. Thus, the expression levels of Cebpb, Klf15, Glut1, and VIdir were dose-dependably decreased by PPT treatment. 
Interestingly, these genes are known to affect hepatic glucose production and insulin sensitivity (Wang et al. 2000, Croniger et al. 2001, Wood \& Trayhurn 2003, Gray et al. 2007).

In conclusion, our data demonstrate that PPT improves glucose tolerance and insulin sensitivity in ob/ob mice. These effects of PPT are due to the activation of $E R \alpha$ signaling and appear to be mediated by Stat3 and G6pc.

\section{Declaration of interest}

$\mathrm{J}-\AA \mathrm{G}$ is a consultant and share holder of Karo Bio AB. The other authors have nothing to declare.

\section{Funding}

This study was supported by grants from European Union Network of Excellence CASCADE, the Swedish Cancer Fund, Novo Nordisk Foundation, Swedish Research Council, the Swedish Diabetes Association, the Strategic Research Foundation (INGVAR II) and Karo Bio AB.

\section{Acknowledgements}

We would also like to thank the BEA core facility, Karolinska Institutet, for assisting with the Affymetrix assays.

\section{References}

Alonso A, Fernández R, Moreno M, Ordóñez P, González-Pardo H, Conejo NM, Díaz F \& González C 2006 Positive effects of $17 \beta$-estradiol on insulin sensitivity in aged ovariectomized female rats. Journal of Gerontology 61A 419-426.

Arner P \& Engfeldt P 1987 Fasting-mediated alteration studies in insulin action on lipolysis and lipogenesis in obese women. American Journal of Physiology 253 E193-E201.

Bailey CJ \& Ahmed-Sorour H 1980 Role of ovarian hormones in the longterm control of glucose homeostasis. Effects of insulin secretion. Diabetologia 19 475-481.

Benjamini Y \& Hochberg Y 1995 Controlling the false discovery rate: a practical and powerful approach to multiple testing. Journal of the Royal Statistical Society. Series B $\mathbf{5 7}$ 289-300.

Bonds DE, Lasser N, Qi L, Brzyski R, Caan B, Heiss G, Limacher MC, Liu JH, Mason E, Oberman A et al. 2006 The effect of conjugated equine oestrogen on diabetes incidence: the Women's Health Initiative randomised trial. Diabetologia 49 459-468.

Borthwick EB, Houston MP, Coughtrie MW \& Burchell A 2001 The antihyperglycemic effect of estrone sulfate in genetically obese-diabetic $(\mathrm{ob} / \mathrm{ob})$ mice is associated with reduced hepatic glucose-6-phosphatase. Hormone and Metabolic Research 33 721-726.

Bryzgalova G, Gao H, Ahren B, Zierath JR, Galuska D, Steiler TL, DahlmanWright K, Nilsson S, Gustafsson JA, Efendic S et al. 2006 Evidence that oestrogen receptor-alpha plays an important role in the regulation of glucose homeostasis in mice: insulin sensitivity in the liver. Diabetologia 49 588-597.

Clegg DJ, Brown LM, Woods SC \& Benoit SC 2006 Gonadal hormones determine sensitivity to central leptin and insulin. Diabetes 55 978-987.

Crespo CJ, Smit E, Snelling A, Sempos CT \& Andersen RE 2002 Hormone replacement therapy and its relationship to lipid and glucose metabolism in diabetic and nondiabetic postmenopausal women: results from the Third National Health and Nutrition Examination Survey (NHANES III). Diabetes Care 25 1675-1680.
Croniger CM, Millward C, Yang J, Kawai Y, Arinze IJ, Liu S, Harada-Shiba M, Chakravarty K, Friedman JE, Pili V et al. 2001 Mice with a deletion in the gene for CCAAT/enhancer-binding protein $\beta$ have an attenuated response to cAMP and impaired carbohydrate metabolism. Journal of Biological Chemistry 276 629-638.

Dahlman-Wright K, Cavailles V, Fuqua SA, Jordan VC, Katzenellenbogen JA, Korach KS, Maggi A, Muramatsu M, Parker MG \& Gustafsson JA 2006 International Union of Pharmacology. LXIV. Estrogen receptors. Pharmacological Reviews $\mathbf{5 8}$ 773-781.

Espeland MA, Hogan PE, Fineberg SE, Howard G, Schrott H, Waclawiw MA \& Bush TL 1998 Effect of postmenopausal hormone therapy on glucose and insulin concentrations. PEPI Investigators. Postmenopausal estrogen/progestin interventions. Diabetes Care 21 1589-1595.

Gao H, Bryzgalova G, Hedman E, Khan A, Efendic S, Gustafsson JA \& Dahlman-Wright K 2006 Long-term administration of estradiol decreases expression of hepatic lipogenic genes and improves insulin sensitivity in $\mathrm{ob} / \mathrm{ob}$ mice: a possible mechanism is through direct regulation of signal transducer and activator of transcription 3. Molecular Endocrinology 20 1287-1299.

Gao Q, Mezei G, Nie Y, Rao Y, Choi CS, Bechmann I, Leranth C, ToranAllerand D, Priest CA, Roberts JL et al. 2007 Anorectic estrogen mimics leptin's effect on the rewiring of melanocortin cells and Stat 3 signaling in obese animals. Nature Medicine 13 89-94.

Gao H, Falt S, Sandelin A, Gustafsson JA \& Dahlman-Wright K 2008 Genome-wide identification of estrogen receptor $\alpha$-binding sites in mouse liver. Molecular Endocrinology 22 10-22.

Geisler JG, Zawalich W, Zawalich K, Lakey JR, Stukenbrok H, Milici AJ \& Soeller WC 2002 Estrogen can prevent or reverse obesity and diabetes in mice expressing human islet amyloid polypeptide. Diabetes 51 2158-2169.

Gray S, Wang B, Orihuela Y, Hong E-G, Fisch S, Haldar S, Cline GW, Kim JK, Peronio OD, Kahn BB et al. 2007 Regulation of gluconeogenesis by Kruppel-like factor 15. Cell Metabolism 5 305-312.

Hansen P, Gulve E, Gao J, Schluter J, Mueckler M \& Holloszy J 1995 Kinetics of 2-deoxyglucose transport in skeletal muscle: effects of insulin and contractions. American Journal of Physiology 268 C30-C35.

Harris HA, Katzenellenbogen JA \& Katzenellenbogen BS 2002 Characterization of the biological roles of the estrogen receptors, $\operatorname{ER} \alpha$ and $\operatorname{ER} \beta$, in estrogen target tissues in vivo through the use of an ER $\alpha$-selective ligand. Endocrinology 143 4172-4177.

Heine PA, Taylor JA, Iwamoto GA, Lubahn DB \& Cooke PS 2000 Increased adipose tissue in male and female estrogen receptor-alpha knockout mice. PNAS 97 12729-12734.

Herbert V, Lau KS, Gottlieb CW \& Bleicher SJ 1965 Coated charcoal immunoassay of insulin. Journal of Clinical Endocrinology and Metabolism 25 $1375-1384$

Inoue $\mathrm{H}$, Ogawa W, Ozaki M, Haga S, Matsumoto M, Furukawa K, Hashimoto N, Kido Y, Mori T, Sakaue H et al. 2004 Role of STAT-3 in regulation of hepatic gluconeogenic genes and carbohydrate metabolism in vivo. Nature Medicine 10 168-174.

Irizarry RA, Hobbs B, Collin F, Beazer-Barclay YD, Antonellis KJ, Scherf U \& Speed TP 2003 Exploration, normalization, and summaries of high density oligonucleotide array probe level data. Biostatistics 4 249-264.

Jones ME, Thorburn AW, Britt KL, Hewitt KN, Wreford NG, Proietto J, Oz OK, Leury BJ, Robertson KM, Yao S et al. 2000 Aromatasedeficient (ArKO) mice have a phenotype of increased adiposity. PNAS $9712735-12740$.

Kanaya AM, Herrington D, Vittinghoff E, Lin F, Grady D, Bittner V, Cauley JA \& Barrett-Connor E 2003 Heart and estrogen/progestin replacement study glycemic effects of postmenopausal hormone therapy: the heart and estrogen/progestin replacement study. A randomized, double-blind, placebo-controlled trial. Annals of Internal Medicine 138 1-9.

Khan A, Hong-Lie C \& Landau BR 1995 Glucose-6-phosphatase activity in islets from ob/ob and lean mice and the effect of dexamethasone. Endocrinology 136 1934-1938.

Kirkman TW 1996 Statistics to use. Available from: http://www.physics.csbsju.edu/stats/, accessed 13 August 2007. 
Kuiper GG, Carlsson B, Grandien K, Enmark E, Häggblad J, Nilsson S \& Gustafsson JA 1997 Comparison of the ligand binding specificity and transcript tissue distribution of estrogen receptors alpha and beta. Endocrinology 138 863-870.

Lai K, Harnish DC \& Evans MJ 2003 Estrogen receptor alpha regulates expression of the orphan receptor small heterodimer partner. Journal of Biological Chemistry 278 36418-36429.

Louet JF, LeMay C \& Mauvais-Jarvis F 2004 Antidiabetic actions of estrogen: insight from human and genetic mouse models. Current Atherosclerosis Reports 6 180-185.

Lundholm L, Movérare S, Steffensen KR, Nilsson M, Otsuki M, Ohlsson C, Gustafsson JA \& Dahlman-Wright K 2004 Gene expression profiling identifies liver $\mathrm{X}$ receptor alpha as an estrogen-regulated gene in mouse adipose tissue. Journal of Molecular Endocrinology 32 879-892.

Margolis KL, Bonds DE, Rodabough RJ, Tinker L, Phillips LS, Allen C, Bassford T, Burke G, Torrens J \& Howard BV 2004 Women's Health Initiative Investigators. Effect of oestrogen plus progestin on the incidence of diabetes in postmenopausal women: results from the Women's Health Initiative Hormone Trial. Diabetologia 47 1175-1187.

Moorthy K, Yadav UC, Siddiqui MR, Sharma D, Basir SF \& Baquer NZ 2004 Effect of estradiol and progesterone treatment on carbohydrate metabolizing enzymes in tissues of aging female rats. Biogerontology 5 249-259.

Rasband WS (1997-2007) Image 1.37v, US National Institutes of Health, Bethesda, Maryland, USA. Available from http://rsb.info.nih.gov/ij/.

Roesch DM 2006 Effects of selective estrogen receptor agonists on food intake and body weight gain in rats. Physiology and Behavior 87 39-44.

Saglam K, Polat Z, Yilmaz MI, Gulec M \& Akinci SB 2002 Effects of postmenopausal hormone replacement therapy on insulin resistance. Endocrine 18 211-214.

Seoane J, Trinh K, O’Doherty RM, Gómez-Foix AM, Lange AJ, Newgard CB \& Guinovart JJ 1997 Metabolic impact of adenovirus-mediated overexpression of the glucose-6-phosphatase catalytic subunit in hepatocytes. Journal of Biological Chemistry 272 26972-26977.

Smyth GK 2004 Linear models and empirical bayes methods for assessing differential expression in microarray experiments. Statistical Applications in Genetics and Molecular Biology 3 Article 3.

Stauffer SR, Coletta CJ, Tedesco R, Nishiguchi G, Carlson K, Sun J, Katzenellenbogen BS \& Katzenellenbogen JA 2000 Pyrazole ligands: structure-affinity/activity relationships and estrogen receptor-alpha-selective agonists. Journal of Medicinal Chemistry 43 4934-4947.
Takeda K, Toda K, Saibara T, Nakagawa M, Saika K, Onishi T, Sugiura T \& Shizuta Y 2003 Progressive development of insulin resistance phenotype in male mice with complete aromatase (CYP19) deficiency. Journal of Endocrinology 176 237-246.

Trinh KY, O’Doherty RM, Anderson P, Lange AJ \& Newgard CB 1998 Perturbation of fuel homeostasis caused by overexpression of the glucose-6phosphatase catalytic subunit in liver of normal rats. Journal of Biological Chemistry 273 31615-31620.

Wallberg-Henriksson H, Zetan N \& Henriksson J 1987 Reversibility of decreased insulin-stimulated glucose transport capacity in diabetic muscle with in vitro incubation. Insulin is not required. Journal of Biological Chemistry 262 7665-7671.

Wang L, Shao J, Muhlenkamp P, Liu S, Klepcyk P, Ren J \& Friedman JE 2000 Increased insulin receptor substrate- 1 and enhanced skeletal muscle insulin sensitivity in mice lacking CCAAT/enhancer-binding protein $\beta$. Journal of Biological Chemistry 275 14173-14181.

Wegorzewska IN, Walters K, Weiser MJ, Cruthirds DF, Ewell E, Larco DO, Handa RJ \& Wu TJ 2008 Postovariectomy weight gain in female rats is reversed by estrogen receptor $\alpha$ agonist, propylpyrazoletriol. American Journal of Obstetrics and Gynecology 199 67e1-67e5.

Westman S 1968 Development of the obese-hyperglycaemic syndrome in mice. Diabetologia 4 141-149.

Wettenhall JM, Simpson KM, Satterley K \& Smyth GK 2006 affylmGUI: a graphical user interface for linear modeling of single channel microarray data. Bioinformatics 22 897-899.

Wiik A, Glenmark B, Ekman M, Esbjörnsson-Liljedahl M, Johansson O, Bodin K, Enmark E \& Jansson E 2003 Oestrogen receptor beta is expressed in adult human skeletal muscle both at the mRNA and protein level. Acta Physiologica Scandinavica 179 381-387.

Wood SI \& Trayhurn P 2003 Glucose transporters (GLUT and SGLT): expanded families of sugar transport proteins. British Journal of Nutrition 89 3-9.

Zimmet P, Magliano D, Matsuzawa Y, Alberti G \& Shaw J 2005 The metabolic syndrome: a global public health problem and a new definition. Journal of Atherosclerosis and Thrombosis 12 295-300.

Received in final form 30 July 2008

Accepted 5 August 2008

Made available online as an Accepted Preprint 29 August 2008 